イブニングシンポジゥム

\title{
司会の言葉 \\ 炎症細胞のトピックス
}

\author{
竹内 万彦, 黒野 祐一 \\ 三三重大学大学院耳鼻咽喉·頭頸部外科学
}

${ }^{2}$ 鹿児島大学大学院耳鼻咽唤科・頭頸部外科学

アレルギー反応の成立にはまず抗原特異的な $\operatorname{IgE}$ 抗体 産生すなわち感作が重要で, IgE抗体が固着したマスト 細胞が再度抗原刺激を受けて様々なメデイエーターを遊 離し，その直接作用とそれによって局所に遊走する炎症 細胞が作用して炎症がもたらされる。しかし，炎症を反 復するに従い, 必ずしも抗原や $\operatorname{IgE}$ E抗体の存在を必要と せず，炎症細胞が独自に働いて炎症の増悪や制御を行う ことが明らかにされてきた。そこで，本イブニングシン ポジウムでは, アレルギー性炎症で重要な働きを担う, 樹状細胞, 好酸球, 好塩基球を取り上げ, その研究にお ける国際的な第一人者である3名の先生に，それぞれの 最新の研究成果を報告して頂くことを企画した。

樹状細胞は抗原提示細胞として重要な役割を担い, 病 原微生物などの抗原を取り込み, そのペプチドをMHC class II分子上に提示して獲得免疫応答を誘導する。ま た, 近年, この細胞が抗原非特異的な構造を認識し, そ れに対応した免疫応答機構すなわち自然免疫応答の誘導 にも関与することが明らかにされている。さらには, 獲 得免疫と自然免疫の両者の協調作用の制御も司ることが 報告されている。こうした樹状細胞のアレルギーにおけ る作用の詳細とその治療への応用について, 土肥 眞先 生 (東京大学) にご講演して頂く。

好酸球はアレルギー性疾患における主要な炎症細胞で
あり, 様々な顆粒蛋白やサイトカイン, 脂質メデイエー ターを放出してアレルギー性炎症を惹起する。とくにロ イコトリエンなどの脂質メデイエーターが重要な役割を 果たし，それゅえこれをターゲットにした治療薬が臨床 で使用されている。ところが, 最近, 好酸球によっても たらされる炎症がある時期になると自然に収束すること から何らかのネガテイブフィードバックが働くことが推 測されていた。浅野浩一郎先生（東海大学）は脂質メデ イエーターのリピドミクス解析によってその機序を明ら かにされた。本講演ではこの好酸球の新たな機能を紹介 して頂く。

好塩基球はマスト細胞と同じくヒスタミンを放出し, モーニングアタック時に増加することからアレルギーに 何らかの関与があることが指摘されていたが, その詳細 は不明である。ところが，この細胞がマス卜細胞とは全 く異なる機能を有し，アレルギー反応や免疫制御に重要 な役割を果たしていることが, 烏山一先生（東京医科 歯科大学）らの研究で明らかにされた。その好塩基球の 知られざるユニークさを先生に扔話し頂く。

本シンポジウムに参加することで, これら炎症細胞の 個々の新しい側面を知るとともに, 相互の関連性を理解 し, 将来の治療戦略へのヒントを掴むことができると期 待している。 